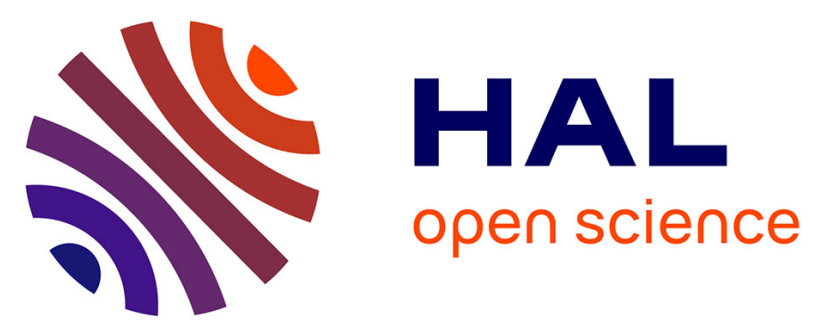

\title{
Adaptability of Mediterranean Agricultural Systems to Climate Change: The Example of the Sierra Mágina Olive-Growing Region (Andalusia, Spain). Part II: The Future
}

Josyane Ronchail, Marianne Cohen, María Alonso-Roldán, Hélène Garcin, Benjamin Sultan, Stéphane Angles

\section{To cite this version:}

Josyane Ronchail, Marianne Cohen, María Alonso-Roldán, Hélène Garcin, Benjamin Sultan, et al.. Adaptability of Mediterranean Agricultural Systems to Climate Change: The Example of the Sierra Mágina Olive-Growing Region (Andalusia, Spain). Part II: The Future. Weather, Climate, and Society, 2014, 6, pp.451-467. 10.1175/WCAS-D-12-00045.1 . hal-01236243

\author{
HAL Id: hal-01236243 \\ https://hal.science/hal-01236243
}

Submitted on 21 Jan 2021

HAL is a multi-disciplinary open access archive for the deposit and dissemination of scientific research documents, whether they are published or not. The documents may come from teaching and research institutions in France or abroad, or from public or private research centers.
L'archive ouverte pluridisciplinaire HAL, est destinée au dépôt et à la diffusion de documents scientifiques de niveau recherche, publiés ou non, émanant des établissements d'enseignement et de recherche français ou étrangers, des laboratoires publics ou privés. 


\title{
Adaptability of Mediterranean Agricultural Systems to Climate Change: The Example of the Sierra Mágina Olive-Growing Region (Andalusia, Spain). Part II: The Future
}

\author{
Josyane Ronchail, ${ }^{*}$ Marianne CoHen, ${ }^{+}$María Alonso-Roldán, ${ }^{\#}$ Hélène Garcin, ${ }^{@}$ \\ BENJAMIN SUlTAN, ${ }^{\&}$ AND STÉPHANE ANGLES ${ }^{+}$ \\ * University of Paris Diderot, Sorbonne Paris Cité, UMR Locean (Sorbonne Universités-UPMC, CNRS, IRD, MNHN), \\ Paris, France \\ ${ }^{+}$University of Paris Diderot, Sorbonne Paris Cité, UMR Ladyss, Paris, France \\ \# Pasos, Participación y Sostenibilidad, Órgiva, Granada, Spain \\ ${ }^{\circledR}$ University of Paris Diderot, Sorbonne Paris Cité, Paris, France \\ ${ }^{\&}$ LOCEAN, Laboratoire d'Océanographie et de Climat: Expérimentation et approches numériques \\ (UMR 7159: UP6, CNRS, IRD, MNHN), Paris, France
}

(Manuscript received 31 July 2012, in final form 16 May 2014)

\begin{abstract}
The adaptability of olive-growing systems to climate change is studied in the Sierra Mágina region (Andalusia) using an interdisciplinary approach that evaluates and makes associations across climate, water resources, and socioeconomic strategies. First, the evolution of rainfall and temperature during the twenty-first century is assessed at the local scale using 17 regional climate model (RCM) simulations. A $15 \%-30 \%$ rainfall reduction is expected in the fall combined with a $7 \%-9 \%$ annual reduction by $2030-50$. Based on a regression model relating yields to rainfall, residual yields (independent of the increasing trend in the present period and from the biennial fruit bearing of the olive tree) are projected to decrease by $7 \%$ and $3.5 \%$ by $2030-50$ for rainfed and irrigated olive groves, respectively. Substantial uncertainties in these results are discussed. A GIS analysis shows a reduction of ground and surface water resources, which are the basis of the present adaptation to rainfall variability, and an uneven potential for adaptation to climate change in the Sierra Mágina region. Despite the important challenges faced by this rural region, there is no consensus among the local key actors regarding adaptation strategies. This is due in part to the diversity among farmers, but also to the different levels of awareness about climate change among all the stakeholders and farmers. Since the projected decline in medium-range future yields is not very high, there might be time and possibilities, especially in the northern part of the Sierra Mágina, to build a local adaptability strategy within the next 20 years that would take into account improved methods of water management and a better economic valorization of olive oil. But at longer time scales, the adaptability of the olive-growing system to yield and water resource declines seems to be threatened.
\end{abstract}

\section{Introduction}

The adaptability of agricultural systems to climate change in regions with irregular and dry climate, such as the Mediterranean basin, is critical for the future economic and social health of many rural areas. Yet, in many Mediterranean regions, climate change scenarios foresee increases in temperatures and in extreme episodes of precipitation, along with an overall decrease in

Corresponding author address: Marianne Cohen. Univ. Paris Diderot, Sorbonne Paris Cité, UMR Ladyss, 5 rue Thomas Mann, Case courrier 7001, 75205 Paris CEDEX 13, France.

E-mail: cohen@univ-paris-diderot.fr rainfall (Christensen et al. 2007; Magnan et al. 2009; Gualdi et al. 2013a,b; Hertig et al. 2013; Stocker et al. 2013), resulting in potential negative consequences for agricultural yields (FAO 2008), natural resources, and landscapes. Olive cultivation is a vulnerable agricultural system that is an appropriate example for studying adaptability to climate change, due to the long life duration of the olive tree, its sensitivity to drought and to high temperatures, and the increasing role olive groves play in the economy of Mediterranean sloping lands (Milli and Gatti 2005; Stroosnijder et al. 2008). While Sofo et al. (2008) consider the olive tree to be a paradigm for drought tolerance in Mediterranean climate, Moriana et al. (2003) show a negative relation between 


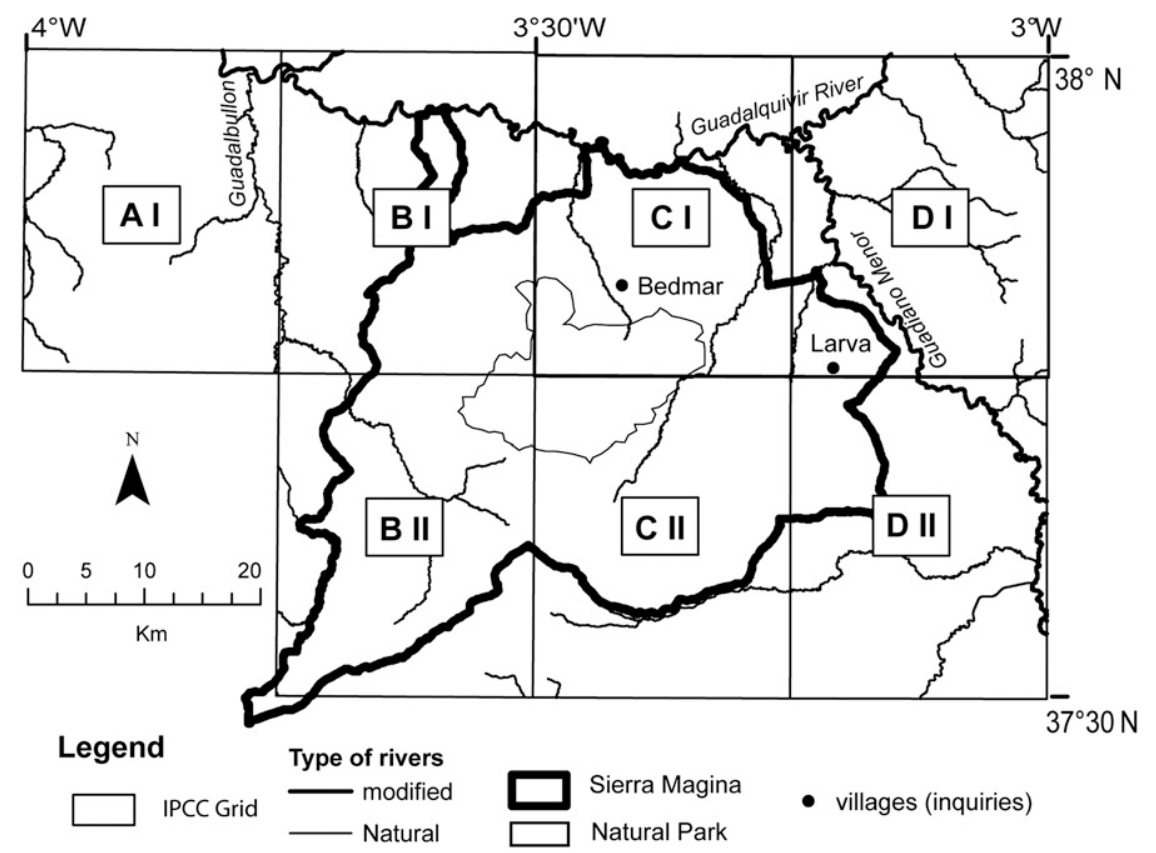

FIG. 1. Location map [Sources: CHG (2010) and the ENSEMBLES Project].

olive yield and evapotranspiration, pointing out that olive yield is sensitive to drought. According to Galán et al. (2008), both rainfall (during spring and summer) and temperatures (maximum and minimum in summer and fall) are parameters affecting fruit production.

The impact of climatic change on these agricultural and social systems is partly known. For example, several authors have demonstrated the effect of the temperature increase on the phenology of olive tree. A trend toward earlier foliation, flowering, and fruit ripening has been observed in southern Spain (Garcia-Mozo et al. 2009). A 1-3-week advance in the release of Olea pollen is projected for the end of the century (Galán et al. 2005) due to the significant correlation between phenological phases and temperature (Avolio et al. 2012). These changes imply future shifts in the optimal latitude for olive cultivation (Orlandi et al. 2012). Climate change is also expected to reduce olive yields (Tunalığlu and Durdu 2012).

The present study is carried out in Sierra Mágina, an olive-growing region in the Jaén Province, in northeastern Andalusia (Spain), in the upper reaches of the Guadalquivir Valley (Fig. 1). This region is highly dependent on olive cultivation with $85 \%$ of arable land devoted to olives, of which $51 \%$ is irrigated (SanchezMartinez and Gallego-Simon 2009). After Spain joined the European Union in 1986, Sierra Mágina benefited from a modernization of olive growing (irrigation, mechanization, use of chemical inputs, harvesting techniques), guaranteed prices, and subsidies. Olive groves fulfill several functions in this region: they are the basis of the local economy, they create cultural landscapes (Araque Jiménez 2008), and in the less intensive groves floristic biodiversity is rather important (Cohen and Sol 2010). Thus the Sierra Mágina's agricultural economy is particularly vulnerable to climate change as well as to market forces for olive oil [see Part I (Cohen et al. 2014, hereafter Part I) for further details].

In Andalusia, climate change projections are rather pessimistic. According to the model projections based on medium-range Intergovernmental Panel on Climate Change (IPCC) emission scenario A1B, rainfall will decrease by $20 \%$ to $30 \%$, while temperature will increase by $+1.8^{\circ} \mathrm{C}$ by $2021-50$ when compared to the end of the twentieth century (Gualdi et al. 2013b) and by $+3^{\circ}$ to $+4^{\circ} \mathrm{C}$ by the end of the century (2080-2100) (Christensen et al. 2007; Rodríguez-Puebla and Nieto 2010; Stocker et al. 2013). These projections would exacerbate the downward trend in rainfall and water resources already observed since the 1950s in southern Spain (Rodrigo et al. 2000; Duran et al. 2006; Lorenzo-Lacruz et al. 2012), the impact of which has been accentuated by an inefficient water management (Gómez-Limón et al. 2012, Lopez-Gunn et al. 2012). According to Kergomard (2013), Sierra Mágina is among the European regions that could be highly impacted by climate change.

In the Andalusian Climate Action Plan, olive groves are expected to perform satisfactorily as climate changes, since olive trees, but not olive yields, are well adapted to water stress and high temperatures (Junta de Andalucía 2007; Méndez Jiménez 2008; Galán et al. 2008). 
The Andalusian Law of Olive Groves (Junta de Andalucía 2011) supports all types of olive groves, from intensive (>200 trees ha ${ }^{-1}$; MAGRAMA-SGT 2013) to olive groves called "traditional" $\left(<200\right.$ trees ha $\left.{ }^{-1}\right)$. Among the main reasons for maintaining olive groves is the positive effect of olive trees in fixing $\mathrm{CO}_{2}$ and, therefore, in mitigating climate change (Sofo et al. 2005). According to this law, climate change is one of the three main threats for olive groves, together with the market changes and the costs of new technology (e.g., mechanization and irrigation modernization). While several authors report low awareness of the local population regarding climate change (Adams et al. 1998; Orlandini et al. 2008), de Castro (2008) observed an increasing concern about this issue from 2001 to 2008.

Whereas, at a long time scale, irrigation and other agronomic improvements have greatly increased olive yields, these increases might be seriously compromised as water scarcity in the region rises due to climate change (Fornes and Pernía 2006). Using the potential soil moisture deficit as an agricultural climatic indictor, Rodríguez-Díaz et al. (2007) project an increase of water required for olive irrigation in the High Guadalquivir Valley of $9 \%$ and $16 \%$ by 2050, under the IPCC A2 and B2 scenarios, respectively. More generally, all irrigated agriculture is considered significantly vulnerable to climate change within the Andalusian Climate Action Plan (Junta de Andalucía 2007). The ongoing Hydrologic Plan of the Guadalquivir Basin Authority (CHG 2010) aims to improve water management in the context of future scarcity and increasing demand, taking into account new requirements to maintain the good ecological and chemical conditions of the river as required by the Framework Directive on Water.

Numerous specialists have analyzed the global and regional impacts and consequences of climate change on olive phenology. But little is known at local level about the influence of climate change on water resource and yields, and on the actions and adaptation strategies of local stakeholders. In Andalusia, despite the proliferation of policies and strategies at the regional level, no steps to implement local sustainable strategies have been taken, leaving local stakeholders searching for information on climate change impacts to improve their decision making.

For these reasons, we have attempted to link three aspects of the adaptability to local climate change in an interdisciplinary study: the climate variability, the agriculture adaptability, and the perception, knowledge, and strategies of local key actors. In Part I, we analyzed the past evolution of climate, water resources, and olive yields, and we assessed how the farmers have adapted to climate variability. In this paper, after a presentation of our methods (section 2), we present our results in section 3. In section 3a, we focus on local climate change in the region of Sierra Mágina. In section 3b, we assess the projections (and associated uncertainties) of olive yields. Then, in section $3 \mathrm{c}$, based on a number of risk factors, we present a detailed spatial map of the adaptability of olivegrowing in Sierra Mágina to changes in climate and water resources. In section 3d, we perform a qualitative analysis of the perception of the farmers and other stakeholders and of their approach to adaptation to climate change. We conclude, in section 4, with a crossdisciplinary summary of the adaptability of olive cultivation in Sierra Mágina.

\section{Data and methods}

Our interdisciplinary method benefited from a team including climatologists, geographers, and sociologists, and on the interactions we developed with local stakeholders. A Sierra Mágina Local Action Group (Asociación para el Desarrollo Rural) requested that our team investigate the future of Sierra Mágina in the context of climate change. The process of combining information from all disciplines, using qualitative and quantitative methods along with the incorporation of local knowledge, led to the improvement of our scientific approach and should promote the acceptance and utilization of our results by the stakeholders (see details in Part I).

\section{a. Data}

\section{1) Climatic, Agronomic, AND GeOGRAPHIC DATA}

Observed present climate is described using daily rainfall and maximum and minimum temperature data from the Spanish State Agency of Meteorology (AEMET) in 29 rainfall gauges and 12 temperature stations (Fig. 1; see also the appendix in Part I).

As global climate models (GCMs) are inadequate to analyze mesoscale features, downscaling is necessary for impact studies. Here, dynamical downscaling is chosen through the use of simulations by 17 regional climate models (RCMs) provided by the European ENSEMBLES Project (Hewitt 2005). Rainfall and temperature simulations are available on a $25 \times 25 \mathrm{~km}$ grid. Sierra Mágina is covered by six grid cells (BI-DII; Fig. 1 ); a seventh point (AI), for comparison, is located in the Guadalquivir valley. The simulations resulting from the use of an intermediate scenario of carbon dioxide emissions [Special Report on Emission Scenarios (SRES) A1B] are available for the 2030-50 period for all the RCMs and allow a good assessment of the simulation uncertainties 
associated with the different models (http://ensemblesrt3. dmi.dk). Unfortunately, the simulations are available for four RCMs only in the time horizon 2080-2100. Moreover, the simulations forced by the SRES A2 high emissions scenario are not available for all the RCMs.

Annual data of rainfed and irrigated olive groves yield are available for the province of Jaén since 1999 on the Agriculture, Food and Environment Department (MAGRAMA) website (MAGRAMA-SGT 2013; http:// www.magrama.gob.es). We collected prior data (195599) from MAGRAMA's provincial registers in Jaén. Geographical data have been gathered from several websites and integrated in a geographical database, using a geographical information system (Arcgis 10.1). The MAGRAMA database SIGPAC (Common Agricultural Policy GIS; MAGRAMA 2006) provides information about land use, and the Guadalquivir Basin Authority (Confederación Hidrográfíca del Guadalquivir) about irrigation (CHG 2010) and current and future water resource (Berbel 2008). (Water resources data are also available at http://www.conocetusfuentes.com/home.php).

\section{2) FARMERS AND STAKEHOLDERS}

We selected 31 interviewees among stakeholders and farmers in order to collect a diversity of opinions on climate change. We performed 15 semistructured interviews with farmers ( 6 small-scale farmers and 9 mediumand large-scale farmers), and with 16 stakeholders representing local and regional institutions [villages' local authorities, local developers, oil professionals, and nongovernmental organization (NGO) representatives]. The farmers are from two villages of Sierra Mágina with different farming systems and climate patterns-Bedmar and Larva (Fig. 1) - which allows us to examine the influence of these factors on climate change perception.

\section{b. Methods}

\section{1) Statistical methods}

The delta method approach is implemented to compare the future simulated conditions at two time horizons (2030-50 and 2080-2100) to the present simulations (1980-2000). This method, already adopted in different climate change impact studies [e.g., for the future of olive flowering (Avolio et al. 2012) and the future of olive yield (Tunalığlu and Durdu 2012)], is useful to remove the bias observed between simulated and observed data (Oettli et al. 2011). The present period is defined as 19802009 because it follows an observed break in rainfall in 1979 (see Part I).

In a first step, differences between simulated future and historical values are computed; they are expressed in percentages for rainfall and in degrees for temperatures.
Differences are calculated for each RCM and each grid cell covering Sierra Mágina. Average values are then computed for all the RCMs, in each grid cell (ENSEMBLE-RCMs), on the one hand, and in all the grid cells for each RCM (ENSEMBLE-GRIDS), on the other hand. In response to the needs and considerations raised by local stakeholders during interviews in November 2009, we focus on the climatic parameters important for the olive trees' physiological needs including moderate maximum temperature and sufficient rain during the blooming and fruit production periods (spring and fall), and sufficient winter rainfall for maintaining the groundwater used for drip irrigation (a parameter considered important by a local conservationist). This local knowledge is consistent with the existing literature about olive groves (Loussert and Brousse 1978; Lavee 1996; Pastor et al. 1999; Moriana et al. 2003). In consequence, three seasons are considered for projected rainfall [December-February (DJF), March-May (MAM), and September-November (SON)], whereas the seasons April-May (AM) and October-November (ON) are taken into account for maximum temperature. Additionally, since Part I demonstrates that the biennial accumulated rainfall (without summer totals) better explains residual olive yield values than seasonal rainfall, the differences between future and present biennial rainfall values (without summer rainfall) are also computed in order to simulate future residual yield values. Residual yields are independent of the increasing trend in the present period (1980-2009) and from the biennial fruit bearing of the olive tree (see Part I).

In a second step, the delta method consists in adding the changes between future and historical rainfall simulations to the observed historical values in order to obtain projections. In this case, these values are seasonal and biennial averaged rainfall in each grid cell.

Then, rainfall projections are used to simulate yields values, by means of the following equations that were developed in Part I:

$$
\begin{gathered}
\mathrm{SRRY}=1.6054 \mathrm{RR}-1817.38 \\
\mathrm{SRIY}=1.2266 \mathrm{RR}-1393.25
\end{gathered}
$$

where SRRY and SRIY are the simulated residual rainfed and irrigated yields respectively (in $\mathrm{kg} \mathrm{ha}^{-1}$ ) and $\mathrm{RR}$ is the biennial rainfall (accumulated during two years) without summer values [June-August (JJA)] in millimeters. Simulated residual yield values are computed for each grid cell and each RCM in order to measure and to estimate the uncertainty of our results. As it was not possible to simulate yields as a function of 


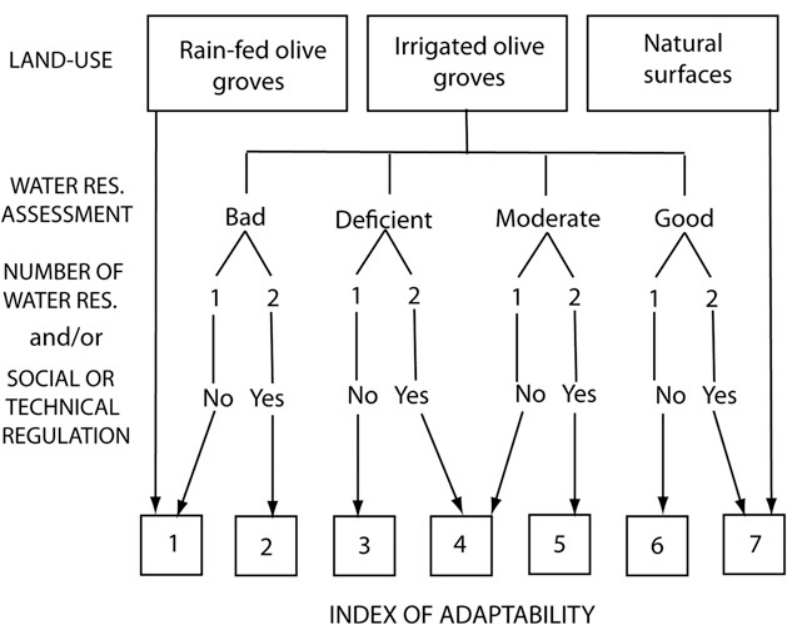

FIG. 2. Decision tree: Index of adaptability.

temperature (see Part I), we do not provide residual yield projections depending on future temperature.

\section{2) MAPPING THE ADAPTABILITY OF IRRIGATED OLIVE GROVES}

Geographical information system (GIS) methods are useful to grasp the spatial and temporal dimension of the adaptability of agricultural systems and of land use and land cover to climate change (Luers et al. 2003; Füssel and Klein 2006; Kergomard 2013).

An initial step is the preparation of a map of water resources potential. Within the GIS, we overlay the projected river flow in 2015, estimated by Berbel (2008), the situation of groundwater resources in 2008 (CHG 2010), and the mean current (1980-2000) and future (2030-50) biennial rainfall deduced from our climatic study, in each grid cell. The worst situation combines a current rainfall less than $500 \mathrm{~mm}$, a future decrease in autumn and winter rainfall by $9 \%$ at the time horizon of 2030-50, degraded groundwater bodies, and very low river flows projected for 2015.

A second step was the preparation of a map of the adaptability of olive growing. We used a decision tree to develop an adaptability index (Fig. 2), taking into account criteria such as the type of land use and land cover, the assessment of water used for irrigation (following the water resource potential developed before), the use of one or two water sources, and the existence of a social (irrigation communities) or technical (dams) regulation. We constructed this multicriteria index through the GIS intersect function. Seven levels were distinguished in the adaptability index; a grayscale corresponds to these levels for irrigated areas, while the darker tone represents the highest value of the adaptability index. The worst rating is assigned to rainfed olive groves (they are mapped with diagonal black stripes on a white background). Natural areas are considered as a resource for future adaptability and correspond to a high level of the adaptability index. To ensure the readability of the map, we left these areas uncolored.

\section{3) SOCIOLOGICAL APPROACH}

In Part I, we identified three target groups within the farmers, depending on the size of their holdings, the role agriculture plays in the household income, and the different farming systems present in Sierra Mágina. Then, we gathered the opinions of the farmers and the views of local key stakeholders about olive growing and climate irregularities. Farmers were also presented with optimistic and pessimistic rainfall projections (based on the RCMs; H. Garcin 2010, unpublished manuscript) for the future climate of Sierra Mágina, and their reactions were recorded.

Two initial hypotheses guided this part of the research. The first hypothesis is that the farmers are not especially concerned about climate change, so this issue is not driving their decisions regarding the future of their farm. According to the stakeholders representing local institutions interviewed in November 2009, the farmers' main worry is the olive oil price. There has been a period of prosperity in the olive sector since 1996 (Araque Jiménez 2008). In the first years after 1996, olive oil prices and subsidies increased and the olive groves areal coverage grew accordingly. Since 2005 , olive oil prices lowered considerably and the future of subsidies is debated within the Common Agrarian Policy reform. Consequently, farmers' concerns are focused on economic issues.

The second hypothesis is that their agricultural practices are increasing farmers' vulnerability to climate change. Mechanization and irrigation are crucial in the current farming systems of Sierra Mágina. They improve productivity and lower costs, substantially increasing the farms' viability. Under a future situation of water scarcity, yields might be seriously compromised since, as shown in Part I, both rainfed and irrigated olive yields depend on rainfall. Moreover, olive groves in mountainous regions present a significant risk for soil erosion (Calatrava Leyva et al. 2007), especially when tillage practices have been commonly used for years, as is the case in Sierra Mágina. This risk may affect soil productivity and farmers' revenues. Soil erosion also reduces the expected positive effect of olive-growing systems in $\mathrm{CO}_{2}$ storage by lowering the soil carbon content (Ballais et al. 2013) and it contributes to increase the sediment load of the rivers and thus to the degradation of water resources.

To examine these hypotheses, the information obtained from the semistructured interviews was extracted and 

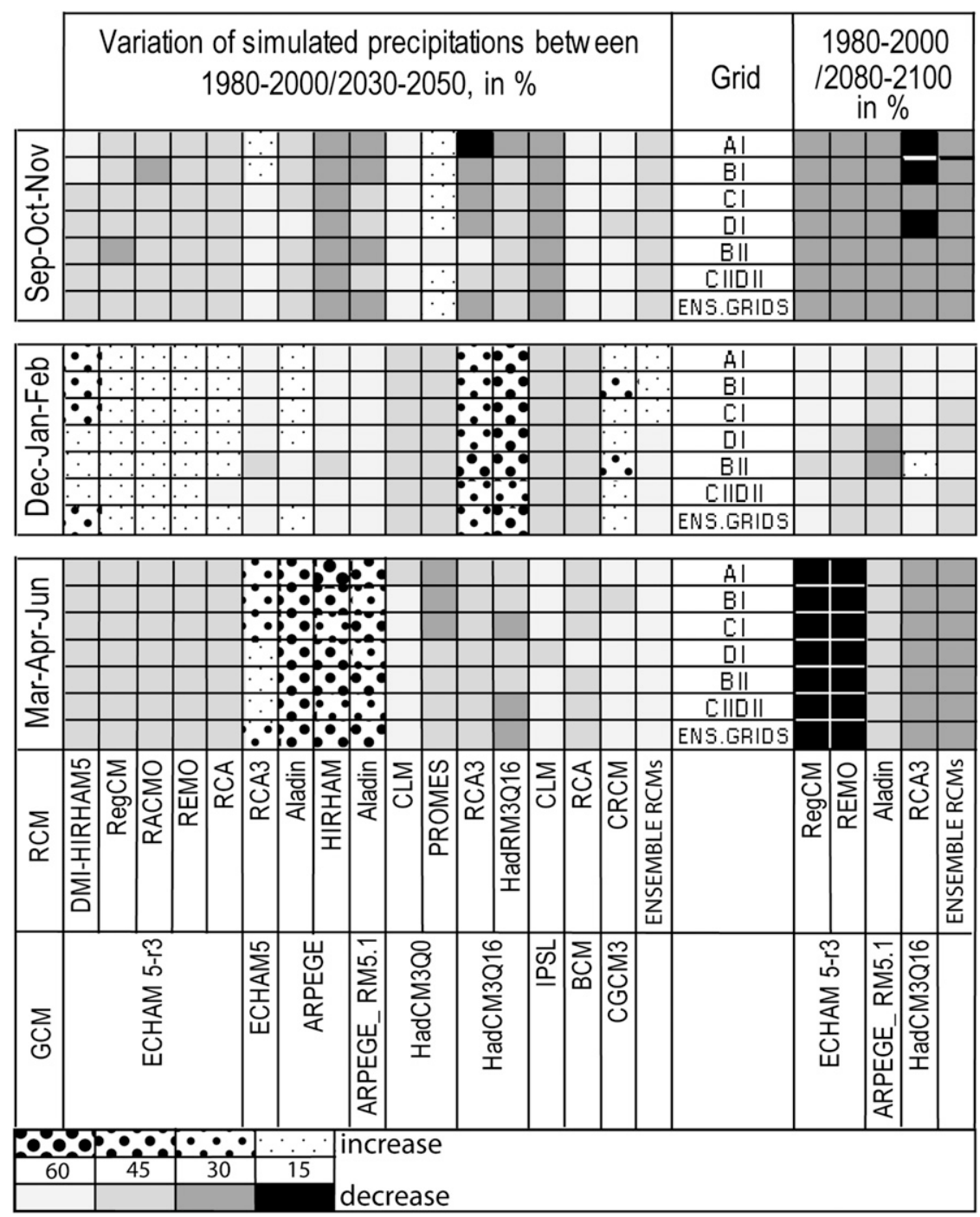

FIG. 3. Seasonal variations (\%) of simulated rainfall between the future (2030-50 and 20802100 ) and the present (1980-2000), using the SRES A1B scenario, by grid cell (ENSEMBLERCMs values are in the right columns of the blocks) and by RCM (ENSEMBLE-GRIDS values are in the bottom lines of the blocks). The global models (GCMs) that force the regional models (RCMs) are indicated.

arranged in a table and interpreted qualitatively. A cognitive scheme was built in order to display the logical relations established by local actors between processes and their causes and consequences (Cohen et al. 2009).

\section{Main results}

\section{a. The future of climate in Sierra Mágina}

\section{1) RAINFALL PROJECTIONS}

In the fall, for the period 2030-50 and under the scenario $\mathrm{A} 1 \mathrm{~B}, 16$ out of 17 models project a rainfall decrease when compared to $1980-2000$ (from $-15 \%$ to $-30 \%$; Fig. 3) (H. Garcin 2010, unpublished manuscript). The rainfall reduction is rather uniform in all the grid cells. In contrast, the projections for spring and winter differ significantly between models (Fig. 3). Average rainfall is expected to decrease by $0 \%$ to $15 \%$ but individual values range from a $30 \%$ decrease to a $60 \%$ increase. Such discrepancies in rainfall projections are often observed and attributed to the different physics in each regional model (Déqué et al. 2007; Oettli et al. 2011). Moreover, it is interesting to notice that in winter, ENSEMBLE-RCMs values (i.e., averages over the ensemble of RCMs) are positive in three grid cells (those located in the Guadalquivir valley and the 

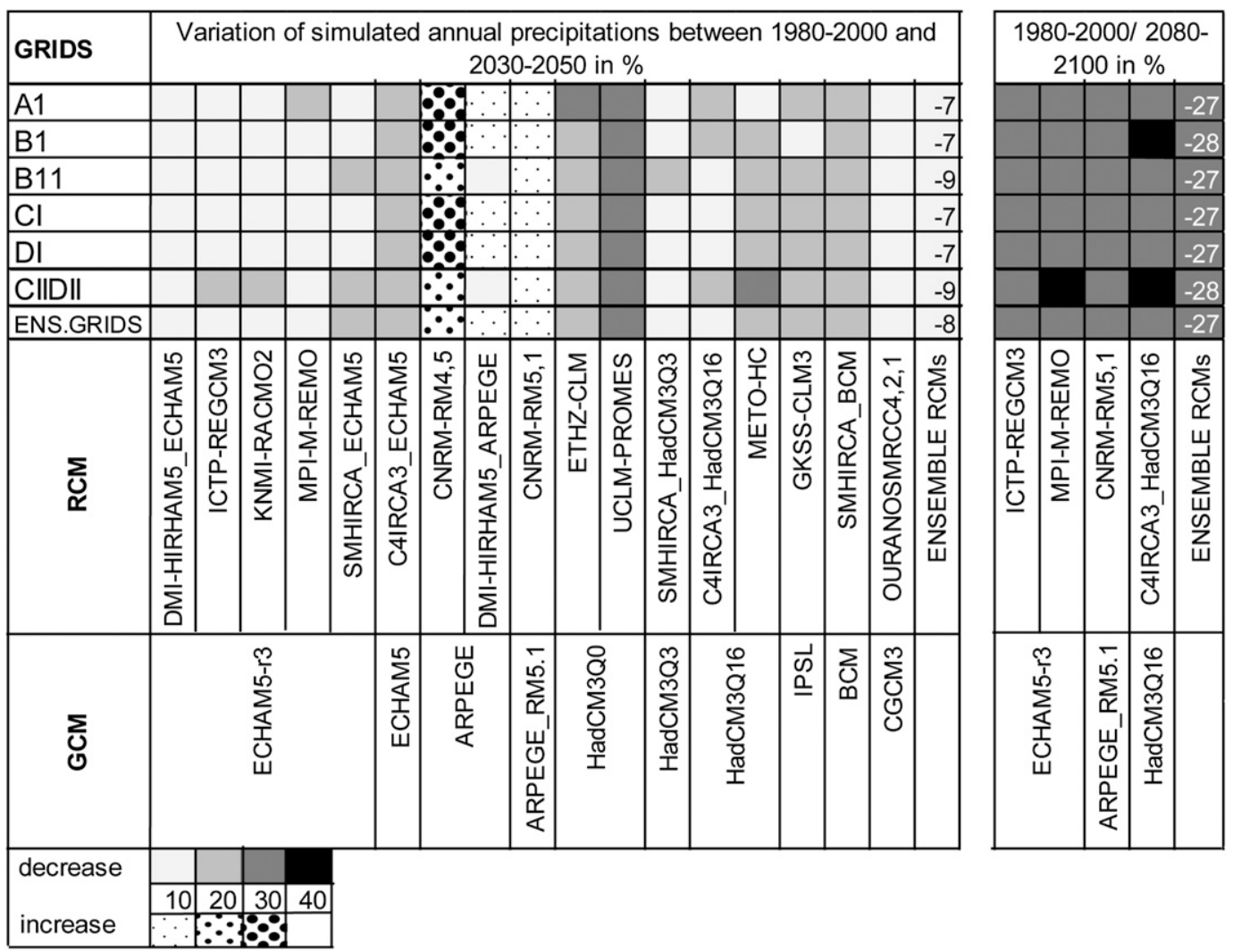

FIG. 4. As in Fig. 3, but for annual variations (\%) of simulated biennial rainfall (without summer values).

northwestern part of Sierra Mágina), while they are negative in the southern and eastern ones.

The analysis of biennial rainfall amounts (without summer values, which represent only $7 \%$ of annual rainfall) that are best correlated to residual olive yield values shows that all the RCMs project a rainfall reduction at the time horizon of 2030-50, with exception of the three models forced by the global model Action de Recherche Petite Echelle Grande Echelle (ARPEGE; Fig. 4). The single values range from $-26 \%$ to $+25 \%$ and the mean value for all grid cells and $\mathrm{RCMs}(-8 \%)$ is similar to the annual value reported by Gualdi et al. (2013a) for the Mediterranean region at the same time horizon and using the same A1B scenario $(-5 \%)$. The rainfall reduction is slightly lower in the northern part of the region, along the Guadalquivir valley $(-7 \%)$ than in the south $(-9 \%)$. Still, the standard deviation among RCMs is high $(9.6 \%)$ while it is 10 times lower between grid cells $(0.8 \%)$.

At the time horizon of 2080-2100, the rainfall decrease is more dramatic. ENSEMBLE-RCMs and ENSEMBLE-GRIDS values (i.e., averages over the seven grid cells for each RCM) are all negative. The decrease is strong in the fall (from $-30 \%$ to $-60 \%$ ); it is more uniform among grid cells and RCMs than in spring (from $0 \%$ to $-60 \%$; Fig. 3). In winter, on the contrary, the reduction is weak (from $0 \%$ to $-30 \%$ ). At annual time scales, the reductions range from $-23 \%$ to $-31 \%$ (Fig. 4); the mean 30\% annual reduction is consistent with the IPCC (Christensen et al. 2007; Stocker et al. 2013) results. The annual rainfall projections are rather uniform between grid cells.

\section{2) MAXIMUM TEMPERATURE PROJECTIONS}

At the time horizon of $2030-50$, there is a spatially uniform increase in maximum temperature in spring and the fall (from $1^{\circ}$ to $2^{\circ} \mathrm{C}$; not shown). However, the individual $\mathrm{RCM}$ values differ from $0^{\circ}$ to $3^{\circ} \mathrm{C}$, the differences being more pronounced in April-May than in October-November. At the end of the century, the maximum temperature projections show potential increases in $5^{\circ}$ to $6^{\circ} \mathrm{C}$ in April-May and in $4^{\circ}$ to $5^{\circ} \mathrm{C}$ in October-November. The differences between RCMs are still substantial, ranging from $3^{\circ}-4^{\circ} \mathrm{C}$ to $6^{\circ}-7^{\circ} \mathrm{C}$.

In conclusion, there are signals of a rainfall decrease and a maximum temperature increase. Small spatial rainfall differences between north and south are assessed in winter and at an annual time scale at the time horizon 


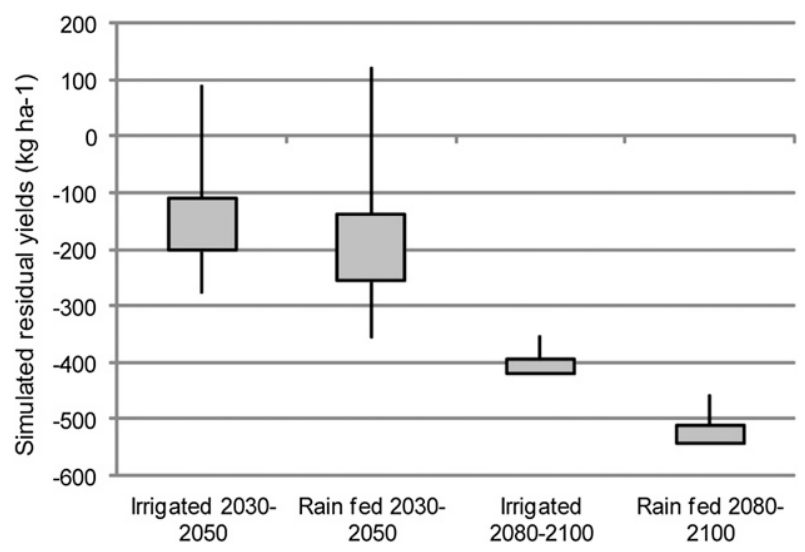

FIG. 5. Annual yields, irrigated and rainfed, simulated by 17 RCMs at the time horizon of 2030-50 and by four RCMs at the time horizon of 2080-2100, at seven grid cells covering the Sierra Mágina. The values represented are percentiles $0.05,0.25,075$, and 0.95 . Mean values are -133 and $-168 \mathrm{~kg} \mathrm{ha}^{-1}$ for irrigated and rainfed yields at the time horizon of 2030-50, respectively, and -395 and $-510 \mathrm{~kg} \mathrm{ha}^{-1}$ at the time horizon of $2080-2100$.

of 2030-50. But the whole territory would be affected, slightly in the near future and severely in a hundred years. Except in the fall, the RCM projections are quite variable, suggesting important uncertainties are present.

\section{b. Yield projections and uncertainties}

To provide an estimation of future yields as requested by the local stakeholders, we first generated models between residual yields and rainfall during the present period (1980-2009), for the whole region. For this, in Part I, we removed the historical trend and the biennial bearing of olive tree in order to obtain residual yields, thereby isolating the variability of yield values that depend mainly on climate variables. We ran these models in each grid cell using future rainfall from each RCM to compute future residual yields. The results are presented herein, as well as a discussion about uncertainties in residual yields projections.

\section{1) RESIDUAL YIELD PROJECTIONS IN 2030-50}

At the time horizon of 2030-50, the residual yields are expected to decrease (Fig. 5). This result is rather reliable as it is projected by 14 of 17 RCMs. The mean decrease is greater for rainfed olive groves $\left(-168 \mathrm{~kg} \mathrm{ha}^{-1}\right)$ than for irrigated ones $\left(-133 \mathrm{~kg} \mathrm{ha}^{-1}\right)$. These quantities represent respectively $7 \%$ and $3.5 \%$ of the mean 1980 2009 yields $\left(2400 \mathrm{~kg} \mathrm{ha}^{-1}\right.$ for rainfed and $3800 \mathrm{~kg} \mathrm{ha}^{-1}$ for irrigated olive groves). Also, Fig. 5 shows a wide range of projected residual yield values. This range is mainly due to the range of rainfall projections by the different RCMs. Indeed, the standard deviation of ENSEMBLE-RCMs values is 10 times greater
(132 $\mathrm{kg} \mathrm{ha}^{-1}$ for irrigated crop, $173 \mathrm{~kg} \mathrm{ha}^{-1}$ for rainfed crop) than the standard deviation computed for the ENSEMBLE-GRIDS values $\left(13.4 \mathrm{~kg} \cdot \mathrm{ha}^{-1}\right.$ for irrigated crops, $17.5 \mathrm{~kg} \mathrm{ha}^{-1}$ for rainfed crops). Finally, these results show that the range of projected residual yields is larger for rainfed than for irrigated olive groves.

\section{2) RESIDUAL YIELD PROJECTIONS IN 2080-2100}

At the end of the century, projected residual yields are less reliable as they result from four RCMs only even though the values are less varied (Fig. 5). However, as the changes in rainfall at such time horizon are rather uniform, and as the four available RCMs are forced by three different GCMs, some trust can be placed in the projected residual yield values. Once again, the changes are more dramatic for rainfed olive groves than for irrigated ones: -510 and $-395 \mathrm{~kg} \mathrm{ha}^{-1}$, respectively. These decreases represent large percentages of the present mean yields: $-22 \%$ for rainfed olive groves and $-11 \%$ for irrigated ones.

\section{3) UNCERTAINTIES IN RESIDUAL YIELD PROJECTIONS}

Projected rainfall reduction will decrease the olive yields, especially for rainfed olive groves, by the middle of the century or sooner; and olive yields will decline further at the end of the century. Nevertheless, projected reductions are variable and remain uncertain. First, our empirical rainfall-yield models are significant but imperfect; indeed, the coefficients of correlation between present residual yields values and rainfall are 0.64 and 0.68 for irrigated and rainfed yields, respectively. Moreover, observed rainfall in each grid cell and consequently projected rainfall do not take into account the topography, as the number of rainfall gauges is too low to allow an interpolation of rainfall. Observed rainfall is simply computed averaging the data of the available gauges in a grid cell. Furthermore, important uncertainties are related to the rainfall projections by the different RCMs, as mentioned before. Other sources of uncertainties that are not measured can be suggested. Our model between climate and residual yield depends on rainfall only because of the lack of reliable temperature data, as explained in Part I. Yet many studies consider that the olive yield also depends on temperature. Consequently, we cannot quantitatively estimate the level of negative effects of maximum temperatures in the future, although it is expected to further increase water stress by increasing evapotranspiration. Also, extreme high temperatures may be critical for olive tree (above $40^{\circ} \mathrm{C}$; Loussert and Brousse 1978) as photosynthesis decreases at $35^{\circ} \mathrm{C}$, growth stops at $40^{\circ}$ (Eris and Baret 2000), and cellular membranes in 


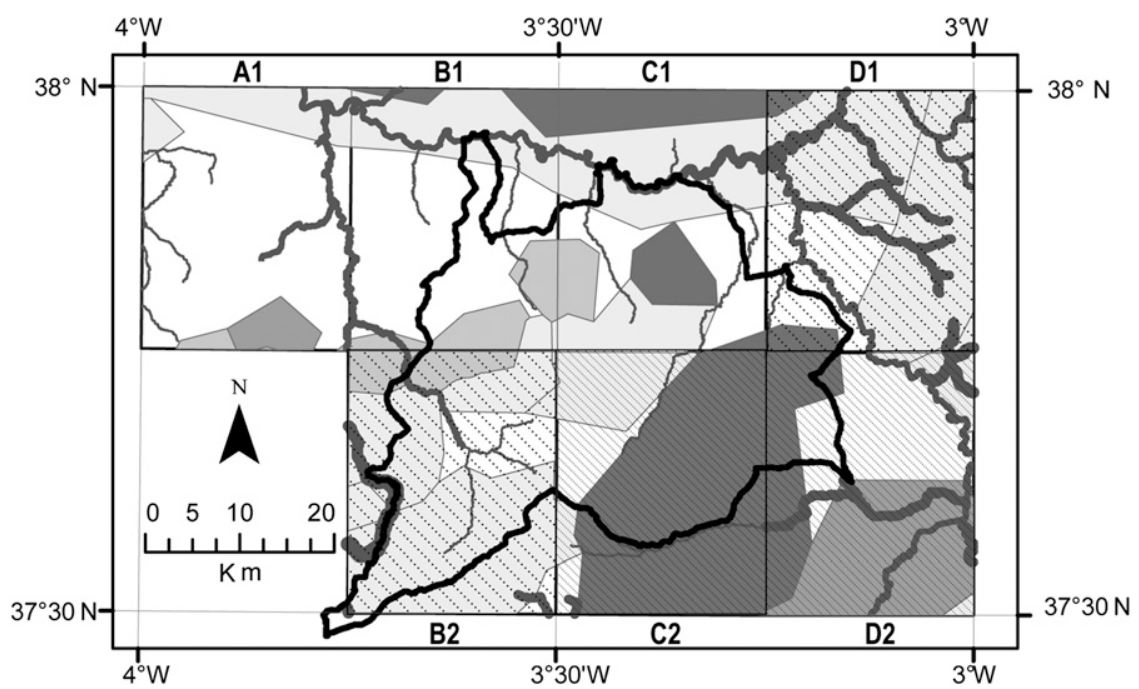

Legend:
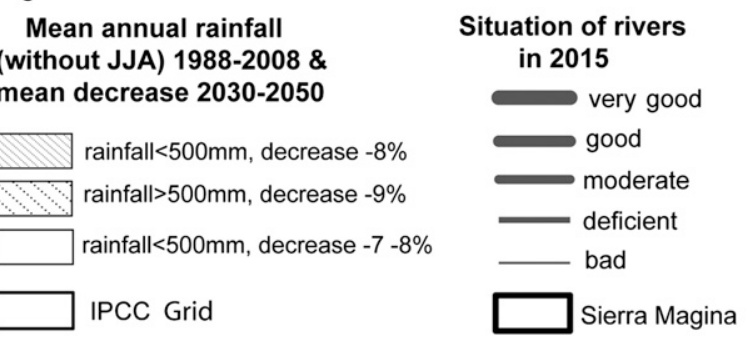
Exploltation rate of groundwater in \% (2008)

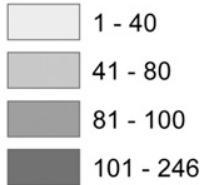

FIG. 6. Water resources projection. Sources: CHG (2010), SIGPAC (2006), Berbel (2008), AEMET, and the ENSEMBLES project.

leaves are damaged above $50^{\circ} \mathrm{C}$ (Cansev 2012). For these reasons, the very high maximum temperature $\left(40^{\circ} \mathrm{C}\right)$ projected in Europe (Beniston et al. 2007) could alter severely the yields, especially at the end of the century. Moreover, the increase of minimum temperature, demonstrated in Part I, may alter the minimum chilling and dormancy required by the olive trees (Orlandi et al. 2005) and consequently the yields. Tunalığlu and Durdu (2012), using one RCM and emissions from the A1B scenario, project in two regions of western Turkey a decrease in rainfed olive yield residuals by 1.8 to 2.5 ton $\left(10^{3} \text { trees }\right)^{-1}$ for the second half of the twentyfirst century (2067-2100), approximately a quarter of the mean present yield (1975-2009). This reduction can be considered as slightly greater than the value we computed $(-22 \%)$ for the period 2080-2100. It may result from the selected RCM and also from taking into account diminished rainfall and increased temperature through a drought index.

Another uncertainty is related to future agronomic progress (as did happen during the period 1955-2009) that might mitigate the yield decrease. It should be noted that yields doubled between the 1950s and the first decade of the twenty-first century due to advances in agronomic science and farming practices, especially drip irrigation. Therefore, if the present trend in yields due to such advances were to continue, the overall yield decrease accounting for rainfall reduction would be modest. On the other hand, our residual yield projections do not take into account a probable shortage in surface and underground water resources that would limit irrigation as it is presently practiced.

\section{c. Adaptability of olive growing to climate change}

\section{1) WATER RESOURCES PROSPECT}

The adaptability of olive growing to climate change depends largely on water resources, as half $(51 \%)$ of the olive groves are currently irrigated. Our map of water resources potential displays differences in the geographical space (Fig. 6) due to the combined effect of several factors. The projected condition of rivers depends on their hierarchy in the basin [only first- or second-rank rivers will be in a good condition in 2015 , according to Berbel (2008)] and on the existence of dams. Along the Guadalquivir River, which is a first-rank river, 


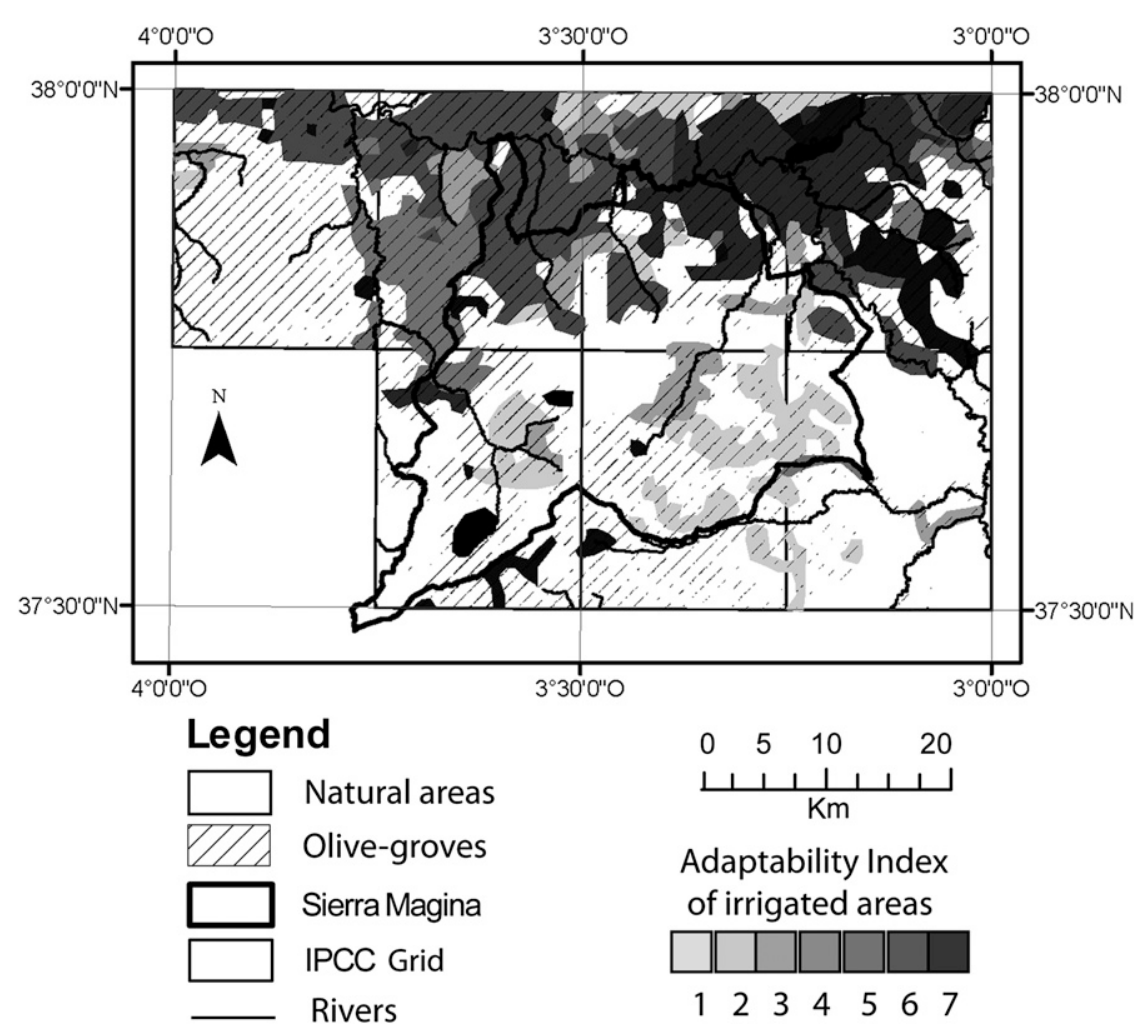

FIG. 7. Adaptability to climate change in Sierra Mágina. Darker tone represents the highest value of the adaptability index. Sources: CHG (2010), SIGPAC (2006), Berbel (2008), and the ENSEMBLES project.

the projected condition ranges from deficient (downstream) to very good (upstream). The groundwater condition in 2008 varies, as shown in Part I, from overexploited aquifers (exploitation rate above $80 \%$ ) to aquifers exploited below $40 \%$, due to rainfall and demand differences as well as other anthropogenic and natural variables. Considering the important role played by winter rainfall in the water recharge and the uneven projections over the grid cells, some existing spatial differences in water resources and climate are expected to be minimized and others increased. The south central grid cell $\mathrm{C} 2$ displays the worst situation: the low projected river flow and the groundwater degradation will be exacerbated by lower rainfall (decrease by around $9 \%$ at the time horizon of 2030-50). In grid cell D2, located eastward, the presence of important rivers and less degraded groundwater bodies mitigates this negative projection. In grid cells B2 (on the southwestern edge of Sierra Mágina) and D1 (on the northeastern edge), rainfall will decline significantly $(-9 \%)$ but the current situation is more favorable: annual rainfall over $500 \mathrm{~mm}$, unexploited groundwater bodies, and rivers with high predicted flow. Finally, despite a current low annual rainfall $(<500 \mathrm{~mm})$, grid cells $\mathrm{A} 1, \mathrm{~B} 1$, and $\mathrm{C} 1$, located in the northern Sierra Mágina, will benefit from advantageous conditions: the presence of the Guadalquivir River and its alluvial groundwater, and a possible increase in winter rainfall, which could minimize the mean drop of annual rainfall $(-7 \%)$.

The expected future situation of water resources could be worse than that projected by Fornes and Pernía (2006). They foresee a rainfall decrease by $5 \%$-consistent with the projections of Gualdi et al. (2013a) — and a water resource decrease by $5 \%-14 \%$ in 2030 , while according to our projections rainfall decrease would reach $7 \%-9 \%$. This water scarcity will have serious consequences as the irrigation water requirements are expected to increase by $9 \%-16 \%$ in the High Guadalquivir olive groves, according to Rodríguez-Díaz et al. (2007).

\section{2) The ADAPTABILITY OF OLIVE GROWING SYSTEMS WITHIN THE SIERRA MÁGINA}

The map representing olive-growing adaptability regarding climatic change displays a considerable contrast within the geographical space (Fig. 7). The northern part of the region is cultivated with irrigated olive groves. There, river discharge is projected to be in the range of deficient to good (CHG 2010). These rivers 
are highly managed by the Basin Authority and the irrigation communities together; in some cases, surface water is used jointly with groundwater. Farmers generally use on-demand piped irrigation systems, which are more flexible and efficient than the older canal systems (Rodríguez-Díaz et al. 2007). These criteria are favorable to the adaptability of irrigated olive groves. This does not mean that irrigated yields will remain constant in the future. The high values of the adaptability index indicate that there are some possibilities to continue the irrigation, mitigating the impact of rain decrease compared to rainfed olive groves.

In contrast, the southeastern part of the region cultivates irrigated olive groves, which depend on either an overexploited aquifer or on rivers with projected low discharge (Berbel 2008). Nevertheless, in this area, the social organization of farmers increases their adaptability to climate change. According to our inquiries in Larva, farmers converted their rainfed cereal crops into irrigated olive groves, due to the recent decrease in rainfall and the drop in cereal prices. As the local water resources were insufficient for irrigation needs (in the $\mathrm{C} 2$ grid cell), they used a water diversion of Guadiana Menor River, located eastward (in the D2 grid cell; not mapped), which is highly controlled by several dams. This use, unofficial in 2009, was later legalized by the Basin Authority. As the projected discharge of the Guadiana Menor River is moderate to good, the farmers' strategy seems sustainable.

The adaptability of rainfed olive groves located in the northwestern parts—outside Sierra Mágina (Guadalquivir valley) or in high slopes-is considered low for different reasons. First, at the end of the twenty-first century, the yield decrease will be twice as important for rainfed olive groves as for irrigated ones (see section 3b). Second, opportunities to develop new irrigation systems are few: they are available only along the Guadalbullon River, on the western part, and on an underexploited aquifer in the southwestern part. Third, such new irrigation systems are very expensive and may not be worthwhile, since olive oil prices are decreasing. Further, increasing irrigation may have a negative influence on the remaining water resources.

Natural areas at medium and high altitudes (Sierra Mágina peaks at $2175 \mathrm{~m}$ ), representing nearly $45 \%$ of the surface, have an advantage. They are located on limestone, which allows a good infiltration of water in the karst and water storage is reinforced by snowfall. Even if snow may decrease in the future due to the increase in minimal temperature, winter rainfall is expected to increase in this northern area, mitigating the negative consequences of the rainfall decrease during the fall. Consequently, these mountains are key areas for future development, which might enhance the adaptation capacity of Sierra Mágina by reducing the stress of further development to the already cultivated areas located downslope.

Regardless of these spatial differences, and despite our qualitative methodology, our results are rather consistent with those of Kergomard (2013), which projected an increase in the vulnerability of the region.

Considering the current situation of water resources, the impact of climate change could be challenging, as water demand is expected to increase both for the existing and future irrigated groves (Rodríguez-Díaz et al. 2007). Meanwhile, within the context of the European Union Water Framework Directive, the river discharges and the aquifers must be maintained at a minimum level in order to improve or preserve their ecological quality.

This shortage in water resources may alter the projected yields for irrigated olive groves, as we assumed in section 3b. Our conclusion is in contradiction to that of the Basin Authority, which considers that the agrarian water deficit will decrease with climate change, due to a better awareness of local key actors regarding water use (CHG 2010). Its conclusion, which seems idealistic, as people will hardly ever accept restrictions in water allocation and as resources will diminish, is however consistent with the function of the Basin Authority, which focuses on improving the water management. This topic will be further discussed in the conclusion.

\section{d. The perceptions and strategies of farmers and stakeholders}

Interviews with local stakeholders and farmers were conducted in order to understand their future farming strategies, their perception regarding climate change, and the adaptability of olive-growing systems.

\section{1) INSTITUTIONAL STAKEHOLDERS}

The interviewees agreed that olive trees are resistant crops, adapted to Mediterranean climate. Some affirmed that olive groves may withstand adverse conditions related to climate change. However, if projections came true (decrease in annual rainfall and temperature raise), they would expect a yield decrease, together with an irrigation reduction. Most of them made reference to erosion when talking about farming practices, being aware that it has been aggravated by former tilling practices and herbicide inputs. Although interviewees were aware of the vulnerability of single-crop farming in the region and of the future climate change, they did not question the agricultural model or imagine other feasible alternatives.

Local developers considered climate change a second chance for Sierra Mágina in the territorial competition 


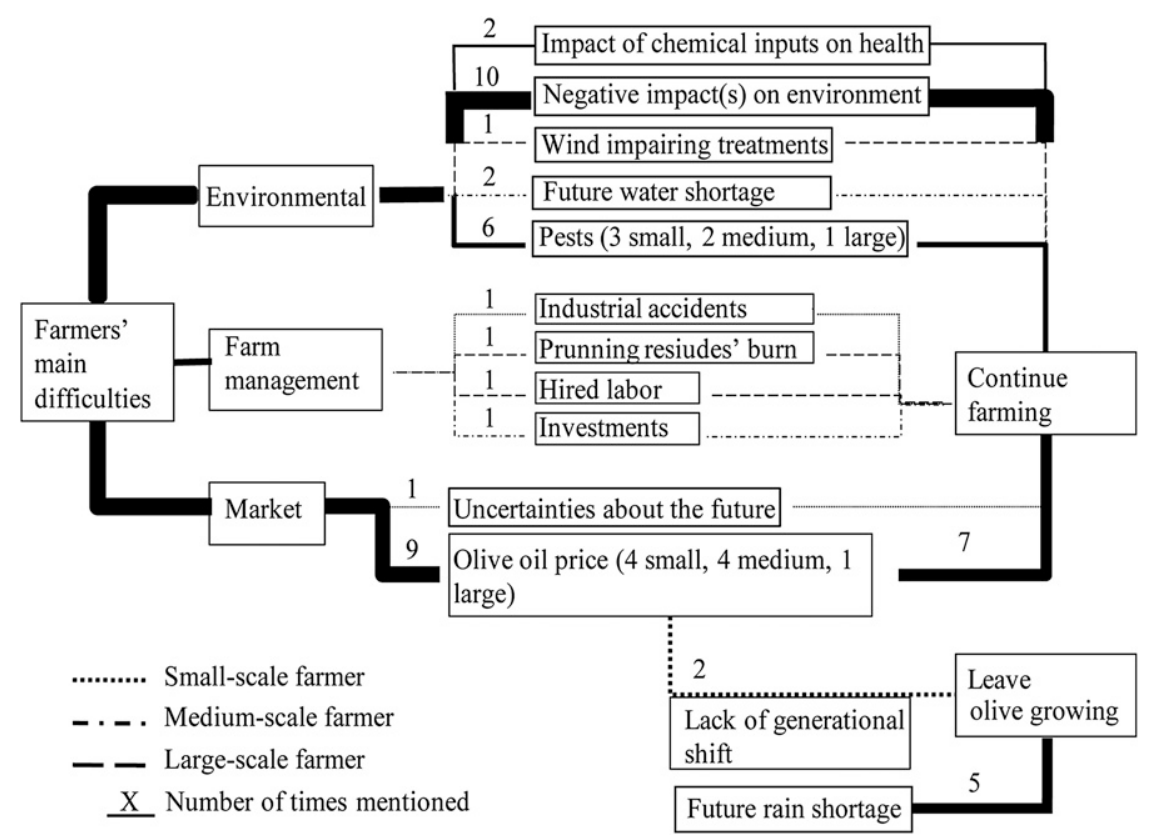

FIG. 8. Cognitive scheme about farmers' main difficulties and future planning.

for olive oil market positioning. Indeed, they aimed to introduce a valorization of pruning residue in order to improve (i.e., to "green") the image of the region, which is nowadays relatively marginalized. This vision is consistent with the Andalusian Law of Olive Groves (Junta de Andalucía 2011), which values and promotes the contribution of olive-growing regions to carbon storage and climate change mitigation.

\section{2) FARMERS}

Farmers of Sierra Mágina were mainly worried about the external market and environmental factors affecting their activity. There was no spontaneous reference to climate change in their narratives and only a quarter of farmers were convinced that it will occur. Only 2 out of 15 farmers criticized single-crop farming. The cognitive scheme (Fig. 8) shows the importance that the different farmers gave to the factors that affect their activity. For small- and medium-scale farmers, the main worry was the low price of olive oil. However, for the large-scale farmers difficulties were more related to the farm management (hired labor, chemical inputs). Regarding their future plans, all farmers intended to continue farming, despite the different difficulties they expressed, providing farming remains financially viable. Only two older farmers, with small holdings and with no expected successors, were planning to leave farming soon.

Regarding farming practices, almost all farmers (11 out of 15) agreed that the main causes of soil erosion are tilling and the use of herbicides, and that the current practice of allowing vegetation cover between the rows of trees, required to earn European subsidies, prevents it. Farmers were very conscious about this risk or about other environmental impacts of their activity (pollution, biodiversity), and less so about the consequences of the water resources' scarcity, despite its importance. Some of them highlighted the significant effect of irrigation in olive production, contending that it allows doubling the yields and avoiding the alternate bearing (which is not true, according to the results of Part I). The farmers interviewed did not imagine an alternative to the olive trees monoculture, even if some of them criticize this system (Table 1). Despite the fact that farmers would not consider abandoning their irrigated farming system, most of them ( 7 out of 9) considered that in rainfed olive groves the "trees are more used to variable conditions." Likewise, they expected that rainfed trees will better cope with future water shortage (both in rainfall and irrigation) than irrigated trees. Only two young farmers (small-scale and large-scale) declared the opposite, agreeing with the results of our study (see sections $3 \mathrm{a}$ and $3 c)$.

Reactions of farmers to climate change projections are shown in Table 2 and Fig. 8. All the farmers reacted similarly to the optimistic projections, declaring they would all undoubtedly continue farming. However, the pessimistic projections generated different reactions: 5 out of 6 small-scale farmers with traditional olive groves showed resignation ("there is nothing I can do against the weather") and resistance capacity ("we have to stand 
TABLE 1. Suggestions of local stakeholders and farmers for olive groves' adaptability.

\begin{tabular}{ll}
\hline \multicolumn{1}{c}{ Vulnerability factor } & \multicolumn{1}{c}{ Adaptability (from interviews) } \\
\hline Soil erosion & $\begin{array}{l}\text { Vegetation cover in the interrows, according to the Common Agricultural Policy requirements } \\
\text { Maintenance of traditional practices such as "ruedos"* }\end{array}$ \\
Rainfall decrease & Gradually decrease in drip irrigation to $500 \mathrm{~m}^{3} \mathrm{ha}^{-1} \mathrm{yr}^{-1}$ \\
Temperature increase & No adaptation has been proposed \\
Lack of generational shift & Enhance profitability of the farming sector by increasing value of the crop (organic farming, \\
& bottled olive oil, etc.) \\
Low olive oil price & A stable price for olive oil established by the European Union \\
Monoculture & No adaptation has been proposed
\end{tabular}

* Preparing the soil under the olive tree canopy for the harvest and in order to restrain interspecies competition.

these conditions"). A medium-scale farmer, who came back to the land after a more than 20 years in town, indicated he would leave farming, and another would sell the farm, but two of them would stand these conditions or adapt their olive-growing activity. Half of large-scale farmers would also leave the activity as soon as the farm is not profitable, but the other half would not. Generally the results correspond to the different sizes of farms. Small-scale farmers were willing to maintain their small plots under favorable conditions, with the aim of covering the costs of their own olive oil. Moreover, olive growing was, for those who were not living in the countryside but in a city, the remaining connection with their rural origins and relatives. It was different for large-scale farmers, who own the farms as capital investments. The medium-scale farmers were the most vulnerable, because their income depends more often on farming and because they invested significantly in the mechanization and irrigation of their olive groves. This personal bet, coupled with the low awareness about future water shortage (Fig. 8), leaves the majority of the medium-scale farmers with no plans for a future alternative to farming.

In conclusion, the first hypothesis of the social study of section $2 b(3)$ has been confirmed, since the farmers' main worry is indeed the olive oil price and not climate change. The second hypothesis has been partially confirmed, as farmers are aware of soil erosion and are increasingly leaving a vegetation cover in the interrows to prevent it, but they are not very aware about water resource scarcity, which could be more critical in the future.
Despite their past drought experience due to the climate irregularity, farmers have a low awareness of future climate change. Indeed, according to Hansen et al. (2012), the natural variability of climate limits people's perception of climate change, but other authors found the contrary (Diggs 1991; Seres 2010; ABS 2009; Merot et al. 2012). Our result is also consistent with the statements of Adams et al. (1998) and Orlandini et al. (2008) but it is opposed to de Castro (2008), which evidenced a growing concern on this issue from 2001 to 2008 in Andalucía. Finally, while all farmers would aim to continue farming, their climate change strategies differ according to the size of their holding and consequently the part agricultural income plays in the household income, while the type of olive-growing system and the current climate seem to have no influence. A larger survey would be useful to confirm these results.

\section{Discussion and conclusions}

Climate, water resources, and olive yields are expected to change significantly in the Sierra Mágina region (Andalucía). At the time horizon of 2030-50, using the SRES A1B scenario and a multi-RCM analysis, annual rainfall is projected to decrease by $8 \%$ when compared to the period 1980-2000. The annual projections vary between the models from a $26 \%$ reduction to a $25 \%$ increase while the reductions are more consistent in the fall (from $-15 \%$ to $-30 \%)$. At the time horizon of $2080-2100$, rainfall is expected to decrease by $30 \%$ at the annual time scale.

TABLE 2. Farmers' reactions to climatic projections and expected performance of olive groves.

\begin{tabular}{|c|c|c|c|}
\hline Holding size & $\begin{array}{l}\text { Reaction to optimistic } \\
\text { prediction }\end{array}$ & Reaction to pessimistic prediction & Olive groves' expected performance \\
\hline Small & $\begin{array}{l}\text { Continue farming, highlighting } \\
\text { water savings }\end{array}$ & $\begin{array}{l}\text { Resignation/resistance (except one } \\
\text { with intensive groves) }\end{array}$ & $\begin{array}{l}\text { Rainfed would perform better (a young } \\
\text { farmer thinks the opposite) }\end{array}$ \\
\hline Medium & Continue farming & Resignation/resistance or leave farming & Rainfed would perform better \\
\hline Large & Continue farming & Leave farming or maintain & $\begin{array}{l}\text { Rainfed would perform better (a young } \\
\text { farmer thinks the opposite) }\end{array}$ \\
\hline
\end{tabular}


In addition to the direct impact of climate change, future projections of water resources for Sierra Mágina indicate other stresses, and these could be worse than that projected by Fornes and Pernía (2006). Our mapping of future water resources shows that climate change impacts will vary across the region due to variations in the current and the future climate, variations in the current and future discharge of the rivers, and differences in social organization and regulation of water resources. The worst prediction is expected in the southeastern part of the Sierra Mágina.

As residual olive yields (independent of the increasing trend in the present period and of the biennial fruit bearing of the olive tree) depend on rainfall, we project decreases of $3.5 \%$ and $7 \%$ in irrigated and rainfed olive groves respectively, at the time horizon of 2030-50 relatively to the 1980-2009 period. The decreases would be greater at the end of the century (11 and $23 \%$ reductions respectively in irrigated and rainfed olive groves). These results have substantial uncertainties due to our climateyield models that do not include temperatures values and to the range of rainfall values projected by the different RCMs we used. But, despite these uncertainties, the quantification of future residual yields' diminution may be useful to local stakeholders who asked us to determine the impacts of climate change on olive production, in order to adapt to the anticipated impacts of climate change.

The development of irrigation systems and other improvements in agricultural practices has resulted in a fantastic increase in olive yields and economic development. However, the observed trend of declining water resources and rainfall seen in Part I and the projections for the twenty-first century do not allow increasing water resource allocations. Sustainable future irrigation systems will have to use water resources more wisely. This is already ongoing. Indeed, we identified several proposals put forward by the local population in Table 1, including the reduction of the water allocation from $1290 \mathrm{~m}^{3} \mathrm{ha}^{-1}(129 \mathrm{~mm})$, as is currently recommended, to 500 to $800 \mathrm{~m}^{3} \mathrm{ha}^{-1}(50-80 \mathrm{~mm})$, and the implementation of water-saving irrigation techniques. Some data show that the mean water utilization of the Irrigation Community Santa Potenciana is already lower than that recommended $\left[856 \mathrm{~m}^{3} \mathrm{ha}^{-1}(85.6 \mathrm{~mm})\right.$ for the period 2002-11; Vicente-Gallego 2012, personal communication] and varies according to the rainfall (see Part I), as observed by Rodríguez-Díaz et al. (2007) in piped irrigation systems in the Guadalquivir catchment.

However, Sierra Mágina contributes to the Guadalquivir River flow and depends on its Basin Authority. Consequently, it could face the increase of water demand at the basin scale, and a possible water competition with the downstream farmers, whose irrigation needs will increase up to $19 \%$ in 2050 under the A2 scenario (e.g., rice crops; Rodríguez-Díaz et al. 2007). Besides, the socioeconomic scenarios elaborated by de Graaff et al. (2008) foresee a trend toward more intensified olive-growing systems in the Jaén Province. This scenario can be questioned as the increase of olive grove surfaces and of the percentage of irrigated groves seem to diminish (see Part I); but if it happened the water demand would require even stronger and more coherent collective strategies than those described above.

These collective strategies would be easier to be implemented if local actors were conscious of these issues, which is only partly true. Our inquiries among farmers and other key stakeholders did not show a consensus on climate change, due to the low awarenessor even the skepticism-of farmers (only 4 farmers out of 15 are convinced about future climate change), particularly small-scale farmers, the largest group overall. Farmers who earn a living with olive growing and have invested in their farms, such as mediumscale farmers, are the most vulnerable. Half of them, similarly to large-scale farmers, would leave the farm in case of rainfall reduction, while most small-scale farmers would withstand the worst climatic conditions, as they did in the past (social resilience; Adger 2000).

During the next 20 years, the moderate projected yield decline should allow sufficient time to elaborate a local strategy, particularly for irrigated olive groves. Unfortunately, most stakeholders think that rainfed trees will better cope with future water shortage than irrigated trees. Along with the efforts made to increase the efficiency of water allocation and to lower water consumption, other agronomic changes should help deal with climate change, such as changing to droughtresistant cultivars, or plantations at a higher altitude as recommended by Orlandi et al. (2012). The Sierra Mágina, at higher altitude, with lower evapotranspiration and temperatures and large natural areas, is more favorably sited than the Guadalquivir Valley to mitigate the impact of declining rainfall and increasing temperatures. However, in a more distant future, the adaptability of olive groves may not be sufficient. Indeed decision making must consider these potential scenarios given the long lifetime of the olive groves.

Moreover, the economic model of olive growing in Sierra Mágina should be critically questioned. Irrigation has allowed an intense increase in the olive yields, but now prices are depressed. Could another model-less productive, more ecological , and market-oriented to provide better prices—be an alternative in Sierra Mágina? These options are part of the future strategies considered 
by Sanchez-Martinez et al. (2011), and are partly resonant with local stakeholders' statements (Table 1). In our research, only individual initiatives of well-off olive growers were observed (vertical integration). These initiatives are, for instance, the mixing of oil varieties in order to elaborate great vintages that are presented to national and international competitions. They contrasted with small-scale producers who, unfortunately, sell their good-quality olives to cooperatives that produce cheap olive oil. An increase in the economic value of the olive oil (currently, nearly $80 \%$ of the production is sold in bulk; Sanz-Cañada and Macías-Vázquez 2008) could mitigate the effect of the projected yield decrease on local economy and the lack of interested next-generation successors, as pointed out by local stakeholders (Table 1).

Nevertheless, we are well aware that the deep economic problems faced by the local actors hinder long-term planning and decision making. Further, the amplitude of long-term predicted reductions in rainfall, water resources, and yields and the uncertainties of the projections restrain the development of climate change adaptation strategies.

In conclusion, although our study is not thoroughly conclusive due to the small size of our sociological sample, the interactions between our team and the locals demonstrated that there is a local knowledge, and a capacity to identify strategies for the future (Table 1). Some of these strategies have been promoted by researchers (e.g., Sanchez-Martinez et al. 2011). Participatory workshops would be useful in order to spread and discuss our results with the local key actors and farmers, as it may help them to build appropriate strategies to adapt to climate change. This local knowledge should be integrated in policies anticipating the impact of climate change both at the short and long term. Despite the various difficulties and limitations we encountered and the complex results of such an interdisciplinary research process, our study confirms the importance of developing scenarios taking into account the socioeconomic context (Hallegatte et al. 2011) and identifying the key regional vulnerabilities.

Acknowledgments. We thank the French Scientific Interest Group (GIS) "Climate, Environment and Society” (CNRS, CEA, UVSQ, UPMC, Ecole Polytechnique, and ADEME) for the financial support it brought to the Regyna (Regionalisation of rainfall and hydrological and agronomical impacts) program, coordinated by Benjamin Sultan (French Institute for Research and Development-IRD and Laboratory of Oceanography and Climate-Locean) who encouraged our participation to the program. Financial support has been also provided by the UMR Ladyss and the University Paris Diderot (Erasmus Program).

Thanks to the DPO Sierra Mágina and the Larva and Bedmar's city hall for the data provision and to the farmers' generous contribution, to the researchersAlia Gana, Philippe Boudes, (UMR Ladyss), Catherine Darrot (AgroCampusOuest), Eduardo Araque Jiménez and José-Domingo Sanchez-Martinez (Universidad de Jaén), Vincente-José Gallego-Simon (Universidad Internacional de Andalucía), Pascal Oettli (Locean)—and master's students- Joelle Salamé (Univ. Paris Diderot, 2010) and Imanol Sinde (AgroParisTech, 2012) — who contributed to this work, to Milena Palibrk and the Pôle Image for the technical support, and to the AEMET and MAGRAMA (data). Finally, we are very grateful to the reviewers who helped us to improve and to edit the manuscript.

\section{REFERENCES}

ABS, cited 2009: Agriculture in focus: Farmers' perception of a change in climate, 2006-07. Australian Bureau of Statistics. [Available online at http://www.abs.gov.au/AUSSTATS/abs@. nsf/Latestproducts/7104.0.55.002Main\%20Features12006-07? opendocument $\&$ tabname $=$ Summary $\&$ prodno $=7104.0 .55 .002 \&$ issue $=2006-07 \&$ num $=\&$ view $=$.]

Adams, R. M., B. H. Hurd, S. Lenhart, and N. Leary, 1998: Effects of global climate change on agriculture: An interpretative review. Climate Res., 11, 19-30, doi:10.3354/cr011019.

Adger, W. N., 2000: Social and ecological resilience: Are they related? Prog. Hum. Geogr., 24, 347-364, doi:10.1191/ 030913200701540465.

Araque Jiménez, E., 2008: Luces y sombras de la expansión olivarera en Sierra Mágina. Sumuntán, 25, 65-96.

Avolio, E., F. Orlandi, C. Bellecci, M. Fornaciari, and S. Federico, 2012: Assessment of the impact of climate change on the olive flowering in Calabria (southern Italy). Theor. Appl. Climatol., 107, 531-540, doi:10.1007/s00704-011-0500-2.

Ballais, J.-L., and Coauthors, 2013: Hydric erosion in Sierra Mágina olive groves (Andalusia, Spain). Prospects for sustainable development. Z. Geomorphol., 57, 1-23, doi:10.1127/0372-8854/ 2012/0088

Beniston, M., and Coauthors, 2007: Future extreme events in European climate: An exploration of regional climate model projections. Climatic Change, 81, 71-95, doi:10.1007/ s10584-006-9226-z.

Berbel, J., cited 2008: Agricultura y agua: Presiones, impactos y medidas. Plan hidrológico de la demarcación Guadalquivir, Taller Agricultura y buen estado ecológico. Seville, Spain, CHG, 1-30.

Calatrava Leyva, J., J. A. Franco-Martínez, and M. C. GonzálezRoa, 2007: Analysis of the adoption of soil conservation practices in olive groves: The case of mountainous areas in southern Spain. Span. J. Agric. Res., 5, 249-258, doi:10.5424/ sjar/2007053-246.

Cansev, A., 2012: Physiological effects of high temperature treatments on leaves of olive cv. Gemlik. Plant Archives, 12, 521-525.

CHG, 2010: Plano hidrológico de la demarcación hydrográfica del Guadalquivir: Memoria, annexos, talleres y appendices. 
MAAME, Delegación General del Agua. [Available online at http://www.chguadalquivir.es/opencms/portalchg/ planHidrologicoDemarcacion/index.html\#.]

Christensen, J. H., and Coauthors, 2007: Regional climate projections. Climate Change 2007: The Physical Science Basis, S. Solomon et al., Eds., Cambridge University Press, 847-940.

Cohen, M., and Coauthors, 2009: Érosion hydrique et paysages dans les montagnes méditerranéennes: Quelques enseignements d'une comparaison spatiale et bibliographique entre la France du Sud et la Catalogne espagnole. Ingénieries: Eau, agriculture, territoires, Écologie de la restauration et ingénierie écologique, T. Dutoit and F. Rey, Eds., 135-156.

-, S. Sol, H. Rosset, and A. Maingre, 2010: Paysage oléicole et diversité biologique: Résultats préliminaires dans la Sierra Mágina. El Olivar: Paisaje, Patrimonio y Desarrollo Sostenible, E. Araque Jiménez, Ed., Universidad de Jaén/ Asssociation pour le développement rural de la Sierra Mágina, 23-55.

— J. Ronchail, M. Alonso-Roldan, C. Morcel, S. Angles, E. Araque Jiménez, and D. Labat, 2014: Adaptability of Mediterranean agricultural systems to climate change: The example of the Sierra Mágina olive-growing region (Andalusia, Spain). Part I: Past and present. Wea. Climate Soc., 6, 380-398, doi:10.1175/WCAS-D-12-00043.1.

de Castro, R., 2008: Cambio climático, representaciones sociales y compromiso personal frente a un problema ambiental global. Consejería de Medio Ambiente, Junta de Andalucía, 40 pp. [Available online at http://www.magrama.gob.es/es/ceneam/ grupos-de-trabajo-y-seminarios/respuestas-desde-la-educaciony-la-comunicacion-al-cambio-climatico/4percepcion_social_ ricardo_decastro_tcm7-13318.pdf.]

de Graaff, J., V.-H. Duran Zuazo, N. Jones, and L. Fleskens, 2008: Olive production systems on sloping land: Prospects and scenarios. J. Environ. Manage., 89, 129-139, doi:10.1016/ j.jenvman.2007.04.024.

Déqué, M., and Coauthors, 2007: An intercomparison of regional climate simulations for Europe: Assessing uncertainties in model projections. Climatic Change, 81, 53-70, doi:10.1007/ s10584-006-9228-x.

Diggs, D. M., 1991: Drought experience and perception of climatic change among Great Plains farmers. Great Plains Res.: J. Nat. Soc. Sci., 1, 114-132. [Available online at http:// digitalcommons.unl.edu/greatplainsresearch/1.]

Duran, J. J., B. Andreo, and F. Carrasco, Eds., 2006: Karst, Climatic Change and Groundwater. IGME, $507 \mathrm{pp}$.

Eris, A., and E. Baret, 2000: Temperate Fruit Crops I. Uludag University, Faculty of Agriculture, $226 \mathrm{pp}$.

FAO, 2008: Climate change adaptation and mitigation in the food and agriculture sector. FAO Tech. Background Doc. HLC/08/ BAK $/ 1,16$ pp.

Fornes, J. M., and J. M. Pernía, 2006: Cambio climático y aguas subterraneas: Visión desde el IGME para los próximos decenios. Karst, Climatic Change and Groundwater, J. J. Duran, J. Andreo, and F. Carrasco, Eds., IGME, 409-420.

Füssel, H. M., and R. J. T. Klein, 2006: Climate change vulnerability assessments: An evolution of conceptual thinking. Climatic Change, 75, 301-329, doi:10.1007/s10584-006-0329-3.

Galán, C., H. García-Mozo, L. Vázquez, L. Ruiz, C. Díaz de la Guardia, and M. M. Trigo, 2005: Heat requirement for the onset of the Olea europaea L. pollen season in several sites in Andalusia and the effect of the expected future climate change. Int. J. Biometeor., 49, 184-188, doi:10.1007/ s00484-004-0223-5. 98-104, doi:10.2134/agrojnl2006.0345.

Garcia-Mozo, and Coauthors, 2009: Olive flowering phenology variation between different cultivars in Spain and Italy: Modeling analysis. Theor. Appl. Climatol., 95, 385-395, doi:10.1007/s00704-008-0016-6.

Gómez-Limón, J. A., J. A. Picazo-Tadeo, and E. Reig-Martínez, 2012: Eco-efficiency assessment of olive farms in Andalusia. Land Use Policy, 29, 395-406, doi:10.1016/j.landusepol.2011.08.004.

Gualdi, S., and Coauthors, 2013a: Future climate projections. Regional Assessment of Climate Change in the Mediterranean, A. Navarra and L. Tubiana, Eds., Advances in Global Change Research, Vol. 50, Springer, 53-118.

climate change projections with realistic representation of the Mediterranean Sea. Bull. Amer. Meteor. Soc., 94, 65-81, doi:10.1175/BAMS-D-11-00136.1.

Hallegatte, S., V. Przyluski, and A. Vogt-Schilb, 2011: Building world narratives for climate change impact, adaptation and vulnerability analyses. Nat. Climate Change, 1, 151-155, doi:10.1038/nclimate1135.

Hansen, J., M. Sato, and R. Ruedy, 2012: Perception of climate change. Proc. Natl. Acad. Sci. USA, 109 (37), E2415-E2423, doi:10.1073/pnas.1205276109.

Hertig, E., S. Seubert, A. Paxian, G. Vogt, H. Paeth, and J. Jacobeit, 2013: Statistical modelling of extreme precipitation indices for the Mediterranean area under future climate change. Int. J. Climatol., 34, 1132-1156, doi:10.1002/joc.3751.

Hewitt, C. D., 2005: The ENSEMBLES project: Providing ensemble-based predictions of climate changes and their impact. EGU Newsletter, 13, 22-25. [Available online at http://static.egu.eu/static/5381/newsletter/eggs/eggs_13. pdf.]

Junta de Andalucía, 2007: Plan Andaluz de Acción por el Clima: 2007-2012 Programa de Mitigación. 148 pp. [Available online at http://www.juntadeandalucia.es/medioambiente/site/pacc/ menuitem.f0b2b1e23eb863d9490cda105510e1ca/?vgnextoid= 803c19a0ee874210VgnVCM10000055011eacRCRD\&vgnextchannel= c00c1e9604273210VgnVCM10000055011eacRCRD\&lr=lang_es.]

_ de Andalucía, No. 205. [Available online at http:// www.juntadeandalucia.es/boja/2011/205/1.]

Kergomard, C., 2013: Climate change and territorial effects on regions and local economies: Fiche de synthèse du rapport final. 6 pp. [Available online at http://www.ums-riate.fr/ documents/Fiche_de_synthese-climate.pdf.]

Lavee, S., 1996: Biología y fisiología del olivo. Enciclopedia Mundial del Olivo, Consejo Oleícola Internacional, 59-106.

Lopez-Gunn, E., P. Zorrilla, F. Prieto, and M. R. Llamas, 2012: Lost in translation? Water efficiency in Spanish agriculture. Agric. Water Manage., 108, 83-95, doi:10.1016/ j.agwat.2012.01.005.

Lorenzo-Lacruz, J., S. M. Vicente-Serrano, J. I. López-Moreno, E. Morán-Tejeda, and J. Zabalza, 2012: Recent trends in Iberian streamflows (1945-2005). J. Hydrol., 414-415, 463475, doi:10.1016/j.jhydrol.2011.11.023.

Loussert, R., and G. Brousse, 1978: L'olivier. Techniques agricoles et production méditerranéennes. G. P. Maisonneuve and Larose, $465 \mathrm{pp}$.

Luers, A. L., D. B. Lobell, L. S. Sklar, C. L. Addams, and P. A. Matson, 2003: A method for quantifying vulnerability, applied to the agricultural system of the Yaqui Valley, 
Mexico. Global Environ. Change, 13, 255-267, doi:10.1016/ S0959-3780(03)00054-2.

Magnan, A., B. Garnaud, R. Billé, F. Gemenne, and S. Hallegatte, and C. M. France, 2009: La Méditerranée au futur: Des impacts du changement climatique aux enjeux de l'adaptation. IDDRI-MEEDDAT Rep., 42 pp.

MAGRAMA, cited, 2006: Visor del SIGPAC nacional. [Available online at http://www.magrama.gob.es/es/agricultura/temas/ sistema-de-informacion-geografica-de-parcelas-agricolas-sigpac-/ visor-sigpac.aspx.]

MAGRAMA-SGT, 2013: Análisis de la superficies de olivar en España. ESYRCE (Encuesta sobre superficie y rendimientos), $30 \mathrm{pp}$. [Available online at http://www.magrama.gob.es/es/estadistica/ temas/estadisticas-agrarias/Olivar2012_tcm7-262578.pdf.]

Méndez Jiménez, J. M., 2008: La adaptación al cambio climático en Andalucía. Tech. communication, Congreso Nacional del Medio Ambiente (CONAMA) 9, Madrid, Spain, MIMARM, $26 \mathrm{pp}$. [Available online at http://www.conama9.conama.org/ conama9/download/files/CTs/2644_JM\%E9ndez.pdf.]

Merot, P., and Coauthors, 2012: Évaluations, impacts et perceptions du changement climatique dans le Grand Ouest: Le projet CLIMASTER. Symp. PSDR3, Pour et sur le Développement Régional: Les chemins du développement territorial, FRA, 25 pp. [Available online at http://prodinra.inra.fr/ft?id=f028C0EA7ECFF-4352-A8FC-AE67C860045Ag\&force $=$ true.]

Milli, S., and S. Gatti, 2005: Mercado agroalimentarios y globalización. CSIC, $238 \mathrm{pp}$.

Moriana, A., F. Orgaz, M. Pastor, and E. Fereres, 2003: Yield responses of a mature olive orchard to water deficits. J. Amer. Soc. Hortic. Sci., 128, 425-431.

Oettli, P., B. Sultan, C. Baron, and M. Vrac, 2011: Are regional climate models relevant for crop yield prediction in West Africa? Environ. Res. Lett., 6, 014008, doi:10.1088/ 1748-9326/6/1/014008.

Orlandi, F., L. Ruga, B. Romano, and M. Fornaciari, 2005: Olive flowering as an indicator of local climatic changes. Theor. Appl. Climatol., 81, 169-176, doi:10.1007/s00704-004-0120-1.

—, T. Bonofiglio, B. Romano, and M. Fornaciari, 2012: Qualitative and quantitative aspects of olive production in relation to climate in southern Italy. Sci. Hortic., 138, 151-158, doi:10.1016/j.scienta.2012.02.029.

Orlandini, S., P. Nejedlik, J. Eitzinger, V. Alexandrov, L. Toulios, P. Calanca, M. Trnka, and J. E. Olesen, 2008: Impacts of climate change and variability on European agriculture: Results of inventory analysis in COST 734 countries. Ann. N. Y. Acad. Sci., 1146, 338-353, doi:10.1196/annals.1446.013.

Pastor, M., Castro, J., Mariscal, M. J., Vega, V., Orgaz, F., Fereres, E. and Hidalgo, J., 1999: Respuestas del olivar tradicional a diferentes estrategias y dosis de agua de riego. Invest. Agrar., 14 (3), 393-404.

Rodrigo, F. S., M. J. Esteban-Parra, D. Pozo-Vázquez, and Y. CastroDíez, 2000: Rainfall variability in southern Spain on decadal to centennial time scales. Int. J. Climatol., 20, 721-732, doi:10.1002/ 1097-0088(20000615)20:7<721::AID-JOC520>3.0.CO;2-Q.

Rodríguez-Díaz, J. A., E. K. Weatherhead, J. W. Knox, and E. Camacho, 2007: Climate change impacts on irrigation water requirements in the Guadalquivir river basin in Spain. Reg. Environ. Change, 7, 149-159, doi:10.1007/s10113-007-0035-3.

Rodríguez-Puebla, C., and S. Nieto, 2010: Trends of precipitation over the Iberian Peninsula and the North Atlantic Oscillation under climate change conditions. Int. J. Climatol., 30, 18071815, doi:10.1002/joc.2035.

Sanchez-Martinez, J. D., and V. J. Gallego-Simon, 2009: La olivicultura ecológica en Sierra Mágina: Una aproximación inicial. El olivar: Paisaje, patrimonio y desarrollo sostenible, E. Araque-Jimenez, Ed., Universidad de Jaén-ADR, 141162.

_ , E. Araque Jiménez, and V. J. Gallego-Simon, 2011: El olivar en la España del Sur: Dinámicas y perspectivas de un monocultivo extremo. Lurralde, 34, 273-299. [Available online at www.ingeba.org/lurralde/.]

Sanz-Cañada, J., and A. Macías-Vázquez, 2008: Appellations d'origine protégée et innovations: La filière « huile d'olive » à Sierra Mágina (Andalousie). Cah. Agric., 17, 542-546.

Seres, C., 2010: Changement climatique et agriculture d'élevage en zone de montagne: Premiers éléments de réflexion. Courr. Environ. INRA, 58, 21-36.

Sofo, A., V. Nuzzo, A. Maria Palese, C. Xiloyannis, G. Celano, P. Zukowskyj, and B. Dichio, 2005: Net $\mathrm{CO}_{2}$ storage in Mediterranean olive and peach orchards. Sci. Hortic., 107, 1724, doi:10.1016/j.scienta.2005.06.001.

_ - S. Manfreda, M. Fiorentino, B. Dichio, and C. Xiloyannis, 2008: The olive tree: A paradigm for drought tolerance in Mediterranean climates. Hydrol. Earth Syst. Sci. Discuss., 12, 293-301, doi:10.5194/hess-12-293-2008.

Stocker, T. F., and Coauthors, Eds., 2013: Climate Change 2013: The Physical Science Basis. Cambridge University Press, 1535 pp.

Stroosnijder, L., M. I. Mansinho, and A. M. Palese, 2008: OLIVERO: The project analysing the future of olive production systems on sloping land in the Mediterranean basin. J. Environ. Manage., 89, 75-85, doi:10.1016/ j.jenvman.2007.05.025.

Tunalığlu, R., and Ö. F. Durdu, 2012: Assessment of future olive crop yield by a comparative evaluation of drought indices: A case study in western Turkey. Theor. Appl. Climatol., 108, 397-410, doi:10.1007/s00704-011-0535-4. 